\title{
GMP Synthase [Glutamine-Hydrolyzing]
}

National Cancer Institute

\section{Source}

National Cancer Institute. GMP Synthase [Glutamine-Hydrolyzing]. NCI Thesaurus. Code C97524.

GMP synthase [glutamine-hydrolyzing] (693 aa, $77 \mathrm{kDa}$ ) is encoded by the human GMPS gene. This protein plays a role in the biosynthesis of guanine nucleotide. 